\title{
Assessment of the Implications of Coal Post-mining Impact on Surface Water at Abandoned Okpara mine in Enugu State
}

\author{
Valentine E. Nnadi ${ }^{1 *}$, Obiageli J. Okolo ${ }^{1}$, Ikenna C. Ezeasor ${ }^{1}$, Nkechi G. Nnoli $^{1}$, Sandra E. Okenwa ${ }^{1}$ \\ 1. Shell Center for Environmental Management \& Control (CEMAC), University of Nigeria, Enugu Campus, \\ Enugu State, Nigeria \\ *Email of the corresponding author: ejour2020@gmail.com;valentine.nnadi@unn.edu.ng (V.E Nnadi)
}

\begin{abstract}
This study examines the coal post-mining impact on surface water at abandoned Okpara mine in Enugu State. Experimental research design was adopted to test the water quality. The water samples were collected and analysed to determine the level of pollution. Hhypotheses were tested using analysis of variance (ANOVA) and the treatment means were separated using Duncan's multiple range test (DMRT). The result of the test of hypothesis one shows that there is no significant difference in the parameters of the water samples within months. For all the parameters, $\alpha$-significant at $\mathrm{P} \leq 0.05$ fall within .207 and .995 . DMRT shows that with the exception of temperature, that there is significant difference in other parameters of the water samples collected at different stations. For the parameters, alpha $(\alpha)$ is significant at $\mathrm{P} \leq 0.05$. The result also shows that with the exception of Lead $(\mathrm{Pb})$, that there is significant difference $(\mathrm{p} \leq 0.05)$ in the heavy metals found in the water samples collected at different stations. The total viable count (TVC) of the bacteria Pseudomonas aurogenosa and Bacillus substilis were $9.0 \times 10^{3} \mathrm{cfu} / \mathrm{ml}$ and $1.2 \times 10^{4} \mathrm{cfu} / \mathrm{ml}$ for the month of July, while in the month of August it was $9.0 \times 10^{3} \mathrm{cfu} / \mathrm{ml}$ and $1.3 \times 10^{4} \mathrm{cfu} / \mathrm{ml}$ respectively. The study concludes that the abandoned coal mine sites contribute to the type of microorganisms found in the water and concentration of heavy metals present in the water samples as well as other physicochemical parameters/indicators of water quality.
\end{abstract}

Keywords: Coal post-mining, Water quality, Microbial load, Pollution, Trace metals

DOI: $10.7176 / \mathrm{JEES} / 11-4-08$

Publication date: April $30^{\text {th }} 2021$

\subsection{Introduction}

Mining has been an important industry involved in the economic development of human society. In Nigeria, huge deposits of coal are found in Enugu state and were extensively mined for more than 50 years (Awaomim, 2013). The mining activities left behind nasty sites along with environmental health consequences. In other words, coal sites have been abandoned without any restoration or cleansed of harmful residues therefore, beaming threats to the surrounding environment. Research has shown that though, coal mined years ago is viewed as one of the important economic activities that contributed to the growth and development of Nigeria (Odoemene, nd; Mba, 2004), the threat posed by the abandoned mines to the surrounding communities ought to have been a major concern to governments, the general public, organizations, individuals and other stakeholders. The researchers report that the overburdens removed from coal mining during the mining activities were usually dropped into low-lying areas, most times filling wetlands, tunnels or other water sources. This made the heavy metals and other contaminants from the abandoned coal mine sites to dissolve and trickle into nearby surface water which disrupt water habitats and pollute drinking water sources. When Pyrite that is present in rocks containing coal seams are exposed to air and water, it forms sulfuric acid and iron hydroxide. Again, in some of the coal mines, acidic water is also found in the underground aquifers. When rain water runoff wash over the rocks, the water becomes acidified and then affect local soils, surface water (rivers, streams and lake) and underground water. This phenomenon is known as Acid Mine Drainage (AMD) and it is very high in active coal mining sites (Chayanan et al., 2014; Geller et al., 1998; Gyang and Ashano, 2010; Williams et al., 1996; Wood et al., 1999). It may still be happening in abandoned sites. Moreover, the microbial growth/survival in any environment is a function of the environment. As a result, the microbial population of the water environment is such that the acidic environment created by the mine waters are supportive.

Enugu, having a long history of intensive mining, provides an excellent place to study the potential long-term consequences of abandoned mine on water environment. Assessment and understanding of these consequences may confidently allow the prioritization of actions to lessen possible imminent impacts connected to abandoned 
mine. The incidence of historic mining in countries with the natural resources implies that mine water discharge is responsible for the single largest source of metals like iron $(\mathrm{Fe})$, zinc $(\mathrm{Zn})$ and copper $(\mathrm{Cu})$ in moving waters (Johnston et al., 2008).

Kitula (2005) asserts that there are some strong scientific bases for concern about chemical pollution originating from coal however, it has not been carefully examined. For instance, a study in Italy found the presence of coal in the water can be a source of some water quality parameters such as chemical oxygen demand (COD), trace metals, acidity, salinity, hydrocarbons as well as possible source of macronutrients (Cidu et al., 2009). In fact, Washington Department of Natural Resources (1996) reports that materials in coal is capable of reacting with seawater to form "localized ocean acidification". All these factors present probable hazards to aquatic organisms as they increase the risk of invasive species taking hold. Though, US EPA (2009) reports that the threshold of the runoff concentrations from an evaluated coal piles were far below and therefore not capable of stressing aquatic organisms, Kitula (2005) reveals that in freshwater streams, runoff concentration can contribute in biodiversity reduction of aquatic creatures in Maryland US. Kitula (2005) further reports that coal can also increase the concentration of macronutrients, more importantly nitrogen and phosphorus in water which may cause eutrophication. Ripley et al., (1996) in a study on environmental effects of mining of Spanish coals found that little phosphorus was mobilized by water. Prasad et al., (2012) in a study of coals in different countries found that $60 \%$ of the phosphorus content in the coal could seep into surrounding surface water. At the same time, heavy metals can seep from coal, though the risk differs significantly and the difference depends on the type and purity of the coal. The authors found that for virtually all the water samples analyzed, there were heavy metal seepages which surpassed international water quality standards. For instance, the concentration of some metals in leachate samples from low-sulfur western US coals surpassed the Canadian water quality standards for protection of aquatic lives. Johnston (2008) found that snails in the Mediterranean around an Israeli power plant were hurt owing to the presence of coal in the water which may be due to high levels of cadmium $(\mathrm{Cd})$.

Production of discharge waters highly rich in mineral is an incidence that has been noticed throughout the world at both active and abandoned mine sites (Wood et al., 1999; Blowes et al., 2003). Mine closure usually brings about increase in the concentrations of dissolved ions, most especially, iron $\left(\mathrm{Fe}^{+}\right)$and sulphate $\left(\mathrm{SO}_{4}{ }^{2-}\right)$ in mine discharge waters owing to the dissolution of pyrite oxidation products formed majorly in the time of operational phase of the mining activities (Younger, 2000). Rock dumped to the surface during mining can also produce the same mine waters through pyrite oxidation, when exposed to oxygen and water (Lottermoser 2010; Nordstrom, 2011). As soon as it is discharged at the surface mine, waters can have costly environmental consequences because the water quality of the recipient streams and rivers would be compromised (Younger, 1995). The pollution of the nearby water sources by AMD is a global issue and basically occur in places where coal or ore sulfides are mined (Young, 1992; Younger, 1992).

Geller et al., (1998) report that in more than hundred acid lakes that were sampled, the values of the $\mathrm{pH}$ were $<4$. These conditions were as a result of the ascending groundwater which brought about the oxidation of the sulfide minerals in the presence of air in the mine dumps. The sulfuric acid $\left(\mathrm{H}_{2} \mathrm{SO}_{4}\right)$ was unceasingly produced which resulted in continual acidic states of the lakes even after the mining operations have been ceased for long. The acid dropped the $\mathrm{pH}$ of the natural water, made it corrosive and incapable of supporting numerous lives in the aquatic environment. AMD often contains, in high concentrations, heavy metals, like iron, Manganese, Aluminum and anions like sulphate $\left(\mathrm{SO}_{4}{ }^{2-}\right)$ as well as elements such as Zinc $(\mathrm{Zn})$, Cobalt $(\mathrm{Co})$, Lead $(\mathrm{Pb})$, Chromium (Cr), Copper (Cu) in trace concentrations (Chayanan et al., 2014; Geller et al., 1998; Gyang and Ashano2010). This led to the suggestion that if such water is to be used, it must be treated. Chayanan et al., (2014) report that $\mathrm{Cl}^{-}, \mathrm{NO}^{3-}, \mathrm{SO}_{4}{ }^{2-}, \mathrm{Na}^{+}, \mathrm{K}^{+}, \mathrm{Ca}^{2+}$ and $\mathrm{Mg}^{2+}$ were found in the lake water of an acidic coal mine reservoir and the major ion concentrations of the $1^{\text {st }}$ three points of sample collection were reported to be $\mathrm{SO}_{4}{ }^{2-}$ and $\mathrm{Ca}^{2+}$, while the $4^{\text {th }}$ point was different. The key source of the dissolved $\mathrm{SO}_{4}{ }^{2-}$ in the lake is the oxidation of pyrite in the presence of air and reservoir water. Heavy metal concentrations in the water and the soil were observed to be $\mathrm{As}, \mathrm{Cd}, \mathrm{Cu}, \mathrm{Fe}, \mathrm{Mn}$ and $\mathrm{Zn}$. Mn has the highest concentration of all the heavy metals found and was found in both the water and soil at the $2^{\text {nd }}$ point of sample collection. The study found low $\mathrm{pH}$ levels in the $2^{\text {nd }}$ point of water sample collection and a high level of electrical conductivity (EC), total dissolved solid (TDS), 
$\mathrm{SO}_{4}{ }^{2-}$. Jarvis and Younger (1997), on investigating the response of benthic invertebrates to AMD pollution, found that the streams showed typical signs of mine drainage pollution: higher EC, high concentration levels of $\mathrm{Fe}, \mathrm{Al}, \mathrm{Zn}$ and $\mathrm{Cu}$ and accumulations of ferric precipitates. EC strongly correlated to most of the studied elements (weighted mean absolute correlation $=0.95$ ) and, then, can be taken as a good proxy indicator for assessments of AMD pollution in water. A study by Williams et al., (1996) on 270 mine discharges found that many of the discharges had a $\mathrm{pH}<3.0$. Generally, water samples from these discharges had high concentrations of acidity, $\mathrm{Fe}, \mathrm{Mn}, \mathrm{Al}$, and $\mathrm{SO}_{4}{ }^{2-}$. Water quality is therefore sternly degraded when mine discharges like this run into streams and rivers. KnÖller et al., (2004) used sulfate as an indicator of the presence of AMD in streams and found that water samples collected from 1978 - 1994 show relatively low level of sulfate prior to 1985, when coal mining began in the basin (secondary data was used here). The median level of sulfate in the collected samples after mining began was about 5 times $>$ the median level in the collected samples before mining.

The subsurface has for long been considered a sterile environment however bacteria play an important role in subsurface chemistry, especially at mining sites. Certainly, all the reaction pathways for pyrite oxidation are usually facilitated by bacteria. The role of the Sulphur bacterial cycle is important at practically all the mine sites because of the biogenesis of metal ores through Sulphur oxidation bacteria (Natarajan, 2008). For instance, the acidithiobacillus group of bacteria play a part in the dissolving and mobilising of copper, iron, zinc, cadmium, arsenic and nickel in mine sites acidic solutions (Natarajan 2008). Pyrite oxidation for a long time has been revealed to be the major control on pollutant release from coal mine sites nevertheless, this oxidation reaction is facilitated by the acidophilic autotrophic bacteria of the acidithiobacillus group which poses as a catalyst in the chemical reactions. These bacteria utilise ferrous iron and Sulphur compounds as a form of energy for reproduction and growth (Mayes et al., 2008). Acidithiobacillus ferrooxidans and Acidithiobacillus thiooxidans are almost ubiquitous at most mine sites and take the responsibility of accelerating the oxidation of metal sulphide (Natarajan, 2008). Acidithiobacillus ferrooxidans is the major actor in the oxidation of pyrite at mine sites, whereas Acidithiobacillus thioxidans cannot oxidize pyrite however, grows through the oxidation of sulphur released from pyrite oxidation. (Natarajan, 2008). Sulphate Reducing Bacteria (SRB) are also of importance at mine sites since they can successfully remove $\mathrm{Fe}, \mathrm{Zi}$ and $\mathrm{Cu}$ as sulphide precipitates (Natarajan, 2008). Nevertheless, this process happens to be time-dependent as SRB are established in anoxic conditions following rebound (Wood et al., 1999). Mayes et al., (2008) state that one of the main influences on net alkaline discharges in mine sites is the outcome of microbial sulphate reduction in the low subsurface preceding the surface discharge (Mayes et al, 2008).

From the literature reviewed here, the compounding environmental and health cost and damages of post impact mining activities on surface water far outweigh their economic and social benefits, the magnitude of which cannot be quantified and such studies has not been conducted in Enugu where coal has also been mined for over five decades. Therefore, the environmental impacts of the abandoned coal mine in Enugu on the quality of the water within the vicinity needs to be investigated.

\subsection{Materials and Methods}

\subsection{The Study Area}

Enugu is located in the Eastern part of Nigeria. It lies about $112 \mathrm{~km}$ East of the River Niger and is surrounded in the Northern hemisphere by many undulating hills together called the Udi hills for being located at the Udi escarpment. Enugu city lies approximately between longitude $07^{\circ} 26^{\prime} \mathrm{E}$ and $07^{0} 37^{\prime} \mathrm{E}$ and between $26^{\circ} 21^{\prime} \mathrm{N}$ and $06^{0} 30^{\prime} \mathrm{N}$ (Wikipedia, 2003). Enugu covers an area of about 200 square kilometers. The area contains hydromorphic soil which is mineral soil morphology that is influenced by seasonal water logging due to underlying impermeable shales.

The Enugu shale underlines Enugu metropolis (see Fig.1). According to Larry (2002) crags of Enugu shale are scarce, but the cores of borehole present Enugu shale as light to dark grey containing bounds of clay ironstone. The uppermost area of Enugu shale weathered to a dirty brown lateritic regolith with a porous characteristic and varies in thickness up to a maximum of $20 \mathrm{~m}$. The water table is $<20 \mathrm{~m}$ below the ground-surface. Enugu shale 
basically constitutes the only known aquifers underneath the metropolis. The undulating terrain of many parts of Enugu accounts for its good natural drainage. Its physical geographies exhibit gradual changes from tropical rainforest to open wood land then to savannah. At present the primary forest land covers in the city of Enugu have reduced severely due to urban development, increased urban population and other anthropogenic activities.

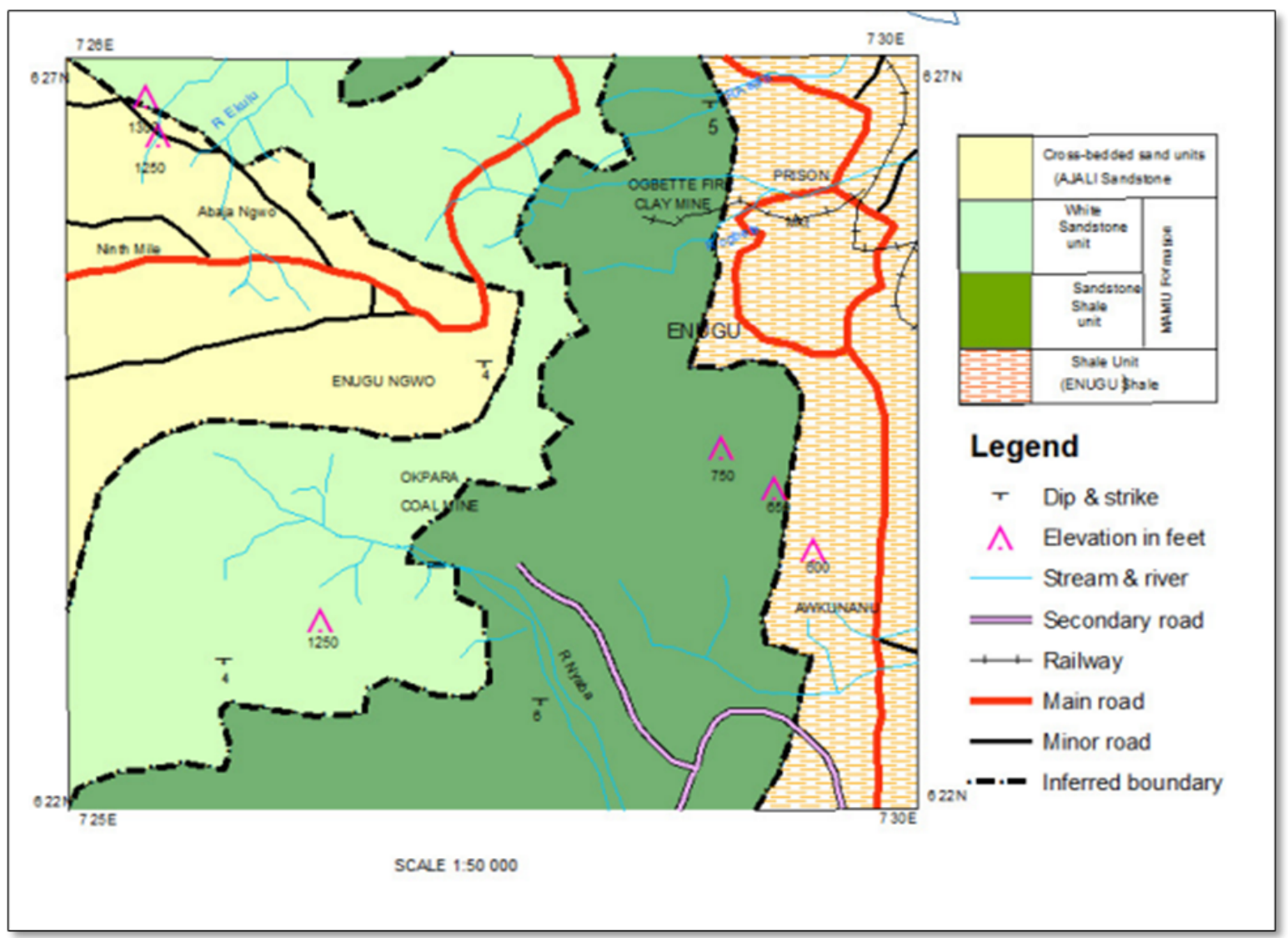

Fig 1: Physiographic and geologic map of the study area.

Source: Enugu State Ministry of Lands and Survey (2012) 


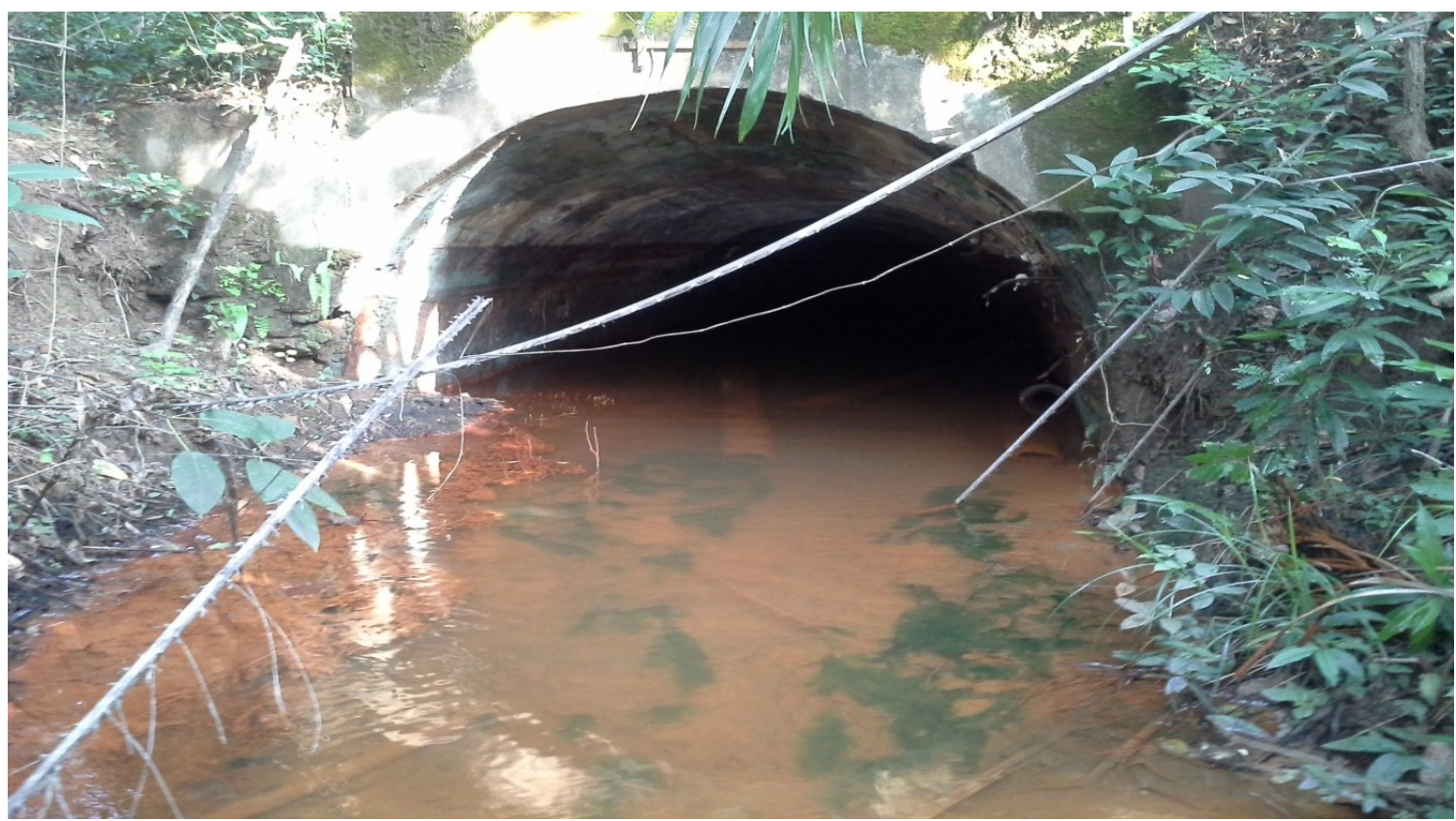

Fig 2: Point source of Oro-obo River at Okpara mine

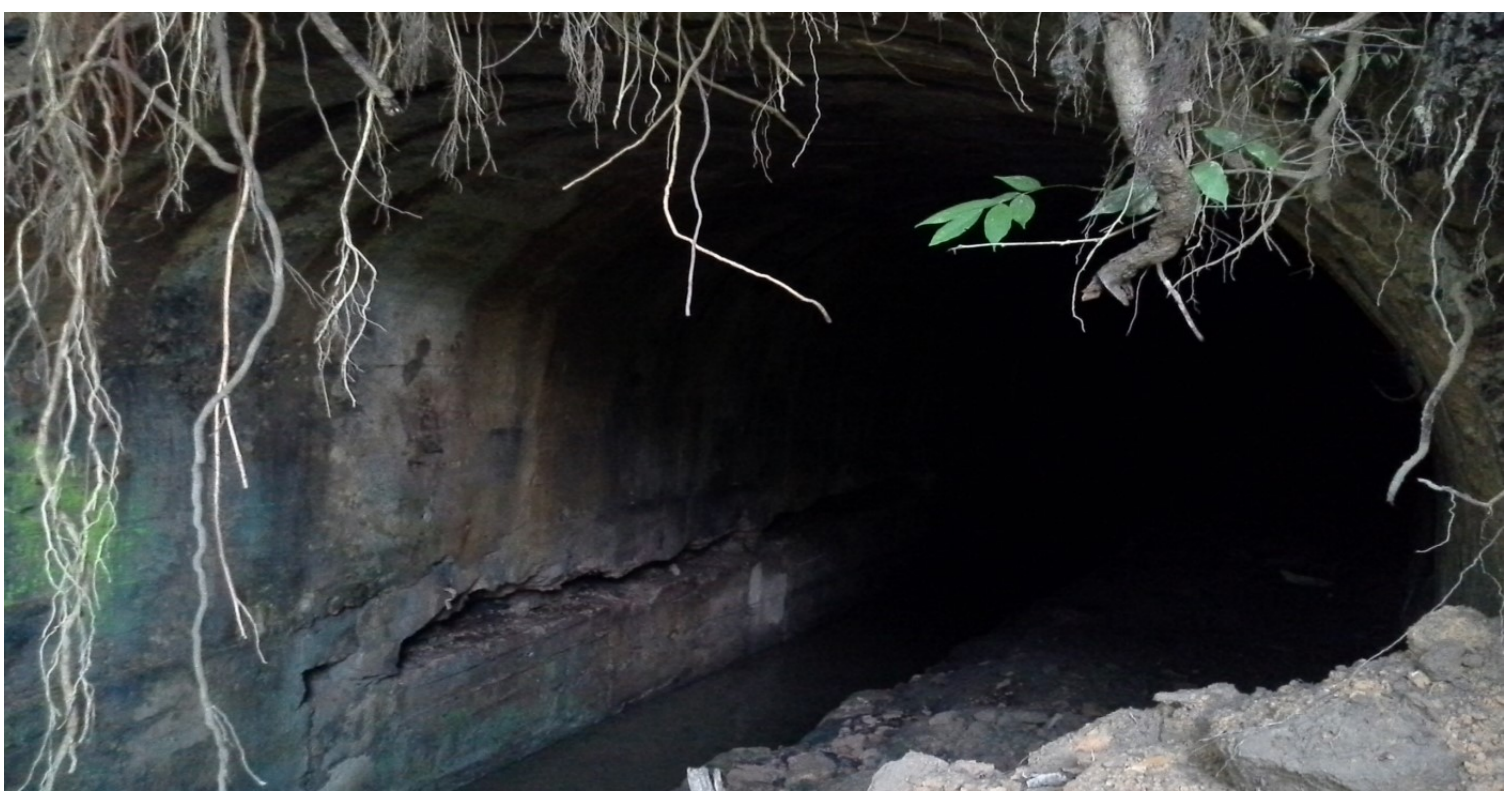

Fig 3: Onigbo mine at Okpara mine; another point source of Oro-obo river. 


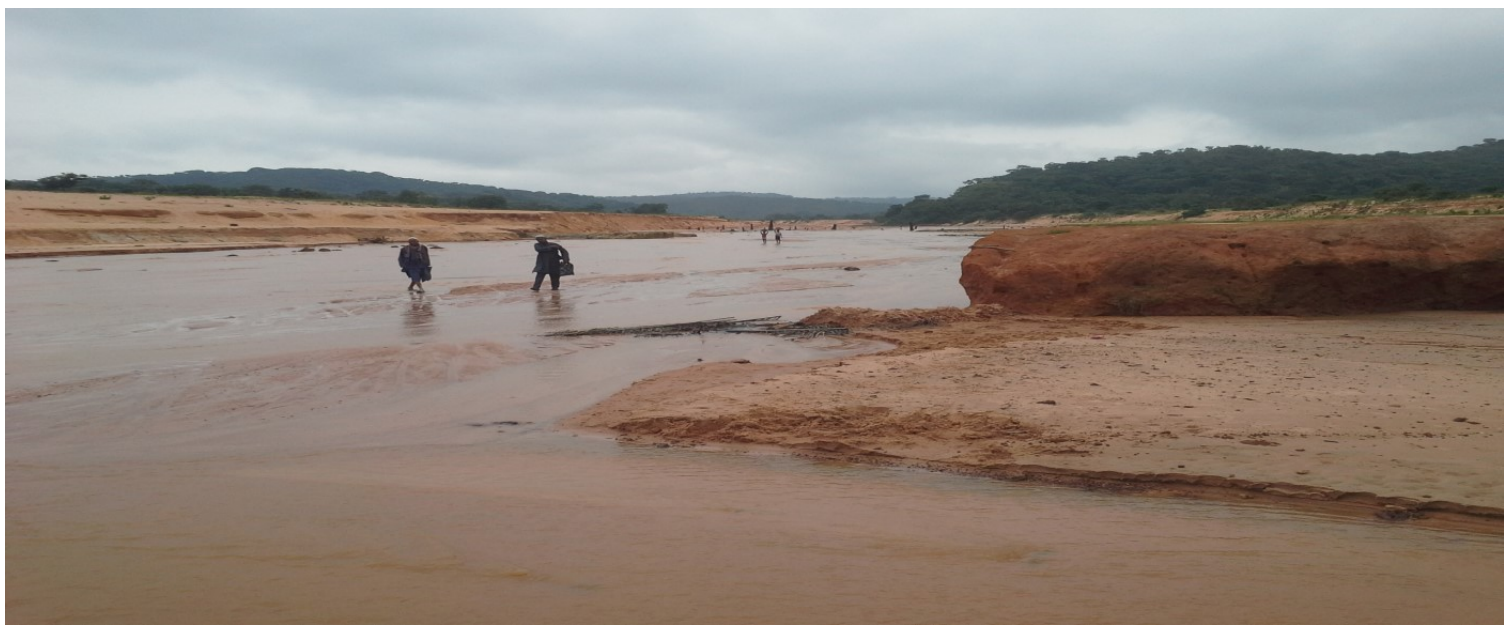

Fig 4: The meeting point of Oro-obo and Nyama River

\subsubsection{Industrialisation}

According to Floyd (1969), the Europeans came to the Enugu area in 1903 for an exploration of the Southern Nigeria Protectorate in search of valuable mineral resources. In 1909 coal was found first in the village of Enugu Ngwo in Udi and Okoga areas. By 1913 it was confirmed to be in commercial or viable quantity. The British, in 1915, began discussions with the indigenous people of the land to acquire the land area so as to lay the Eastern railway-line and build a colliery. After acquiring the land, the colliery was built at the bottom of the Udi Hills and was named Enugu Coal Camp to differentiate it from Enugu Ngwo which overlooks Enugu city from above a scarp on the western part of Enugu. Udi mine was opened in 1915 and happened to be the first coal mine in the Enugu area but was later shut down after two years and substituted with the Iva Valley mine.

Enugu became a major coal mining area and the only significant one in West Africa (Odoemene, nd). The Eastern railway-line linking Enugu and Port-Harcourt was constructed in 1916 to export the coal through the Port-Harcourt seaport. The built-up area of Enugu then comprised the part of Enugu that was reserved for Europeans set up by the colonial government and the section developed for African residents. By 1917 the city publicly gained township status and was nicknamed Coal City. On the African side of Enugu city, a fast entry of migrant workers stimulated the development of squatter camps on the Udi Hills near the coal mines and the Iva Valley area (Mba, 2004). The population of coal miners that were employed in Enugu rose from 6,000 (of mostly Udi men) in 1948 to 8,000 in 1958. The mining continued till when the demand for coal as source of energy dropped and the mining activities ended which resulted to the mine sites being abandoned. Some of the abandoned mines turned to point source of flowing waters. The Point source of Oro-obo river at Okpara mine is shown in Figures 2 and 3 to where it meets with the Nyama river as shown in figure 4. The general flow of water towards the stream channels from ground water is common in the abandoned mines especially as seen in Okpara mine and Onigbo mine respectively. These mines are located in Enugu South local government area of Enugu State, Nigeria.

\subsection{Sample Collection}

Eight (8) samples were collected, four (4) samples in the month of July and another four (4) in the month of August. In the month of July, first sample was collected $100 \mathrm{~m}$ upstream of Nyama river from the point of discharge and labeled Upstream primary (USp). Second sample was collected the point of discharge (PD) of the waste water from the abandoned mine. Third sample was collected 100m upstream of Orobo River from the point of discharge and labeled USs (Upstream secondary). Fourth sample was collected 100m downstream from the point of mine water discharge and labeled Downstream primary (DSp). The samples were labelled for easy identification. In the month of August, sample collection was repeated at the same stations. These water samples were subjected to laboratory analysis of which relevant parameters of water quality, that is, the physical, chemical, and biological compositions were analysed. 
For quality control, surface water samples were collected with sterilized new plastic gallons free of oil and grease or other sources of water pollution were used. The one (1) liter capacity gallons were first rinsed with hydrogen peroxide kept at room temperature to prevent volatilization and condensation or oxidation and absorption on the walls of the container. The GPS readings were taken as soon as the calibrations normalize.

\subsection{Water Quality Parameter Determination/Laboratory analysis}

The water samples collected were analysed in the laboratory to determine its quality using the following parameters: $\mathrm{pH}$, electrical conductivity (EC), acidity (AC), alkalinity (AL), total solids (TS), total dissolves solids (TDS), total suspended solids (TSS), calcium, magnesium, phosphate, nitrate. Heavy metals like lead, copper, iron and zinc were also analyzed as well as E-coli and total coliform. This determines the status of both the physico-chemical and microbial quality of the water samples. Analytical methods for determining physicochemical parameters were used in line with methods of the Association of Official Analytical Chemists (AOAC, 2005). The microbial loads of the water samples were determined using serial dilution techniques while characterization was done by macro- and microscopic examination of colonial morphology, Gramm-staining techniques and biochemical tests using Bergey's Manual of Determinative Bacteriology (Holt, 1993).

\subsection{Results and Discussion of Findings}

\subsection{Physico-chemical parameters and Trace Metals of the water samples}

Results of the mean values of physicochemical parameters of the water samples from the coal mined site are shown in table 1 (see Appendix I). The table shows that TDS mean values at USp, DP, USs and DSp are $62.5 \mathrm{mg} / 1,20.25 \mathrm{mg} / 1,10.0 \mathrm{mg} / 1$ and $20.0 \mathrm{mg} / 1 \mathrm{respectively.} \mathrm{However,} \mathrm{all} \mathrm{the} \mathrm{recorded} \mathrm{values} \mathrm{are} \mathrm{within} \mathrm{WHO}$ acceptable limit. EC recorded $49.7 \mu \mathrm{s} / \mathrm{m}, 49.54 \mu \mathrm{s} / \mathrm{m}, 200 \mu \mathrm{s} / \mathrm{m}$ and $30 \mu \mathrm{s} / \mathrm{m}$ at USp, DP, USs and DSp respectively, which are all within WHO limit. Recorded mean values of temperature were $27.45^{\circ} \mathrm{C}, 28.0^{\circ} \mathrm{C}$, $27.5^{\circ} \mathrm{C}, 30^{\circ} \mathrm{C}$ at points of USp, DP, USs, Dsp respectively. The mean values of TSS at USp, DP, USs and DSp were $121.65 \mathrm{mg} / 1,111.0 \mathrm{mg} / 1,116.45 \mathrm{mg} / 1$ and $20.99 \mathrm{mg} / 1$ respectively. The mean values of TS at USp, DP, USs and DSp were $103.7 \mathrm{mg} / 1,106.7 \mathrm{mg} / 1,111.55 \mathrm{mg} / 1$ and $11.0 \mathrm{mg} / 1$ respectively. Potential Hydrogen $(\mathrm{pH})$ values of the water samples at respective points of USp, DP, USs and DSp are 5.95, 6.90, 7.60 and 6.00 which are within WHO acceptable limit. Nitrate $\left(\mathrm{NO}_{3}\right)$ recorded $10.13 \mathrm{mg} / 1,5.69 \mathrm{mg} / 1,5.46 \mathrm{mg} / 1$ and $2.25 \mathrm{mg} / 1$ at USp, DP, USs and DSp respectively. The mean values of $\mathrm{SO}_{4}$ were 430.0, 79.52, 79.82 and 64.90 at USp, DP, USs and DSp respectively. Recorded $\mathrm{Cl}_{2}$ mean values were $279 \mathrm{mg} / 1,94.6 \mathrm{mg} / 1,94.1 \mathrm{mg} / 1$ and $45.1 \mathrm{mg} / \mathrm{l}$ at USp, DP, USs and DSp respectively. The mean values of $\mathrm{PO}_{4}$ at USp, DP, USs and DSp were $2.08 \mathrm{mg} / 1,0.80 \mathrm{mg} / 1,0.78 \mathrm{mg} / 1 \mathrm{and}$ $0.47 \mathrm{mg} / 1$ respectively. The mean values of AL at USp, DP, USs and DSp were $13.4 \mathrm{mg} / 1,10.09 \mathrm{mg} / 1,10.09 \mathrm{mg} / 1$, $10.12 \mathrm{mg} / 1$ and $13.10 \mathrm{mg} / 1$ respectively. Recorded AC mean values were $3.20 \mathrm{mg} / 1,1.95 \mathrm{mg} / 1,1.95 \mathrm{mg} / 1$ and $2.93 \mathrm{mg} / 1$ at USp, DP, USs and DSp respectively. Recorded values of $\mathrm{SO}_{4}, \mathrm{NO}_{3}, \mathrm{PO}_{4}$ and $\mathrm{Cl}_{2}$ are within the WHO acceptable limit.

Results of the concentration of trace metals in the water samples from the coal mined sites are shown in table 2 (see Appendix II). The table shows that the values of $\mathrm{Zn}$ at USp is $1.51 \mathrm{mg} / 1,1.32 \mathrm{mg} / 1$ at both DP and USs but $1.04 \mathrm{mg} / 1$ at DSp. However, the mean values are within WHO acceptable limit of surface flowing water. Potassium (K) recorded $26.11 \mathrm{mg} / 1,15.90 \mathrm{mg} / 1,15.84 \mathrm{mg} / 1$ and $8.34 \mathrm{mg} / 1$ at USp, DP, USs and DSp respectively. The recorded mean value of $\mathrm{Cu}$ at USp was $0.06 \mathrm{mg} / 1$ and $0.02 \mathrm{mg} / 1$ for DP and USs. Cu was not available for detection at DSp. The values of Na were $54.5 \mathrm{mg} / 1,8.45 \mathrm{mg} / 1,8.40 \mathrm{mg} / 1$ and $6.28 \mathrm{mg} / 1$ at USp, DP, USs and DSp respectively. From indication, it is only the value of $\mathrm{Cu}$ at USp that is above WHO accepted limit. The mean values of Ca at USp, DP, USs and DSp recorded $22.12 \mathrm{mg} / 1,9.17 \mathrm{mg} / 1,9.1 \mathrm{mg} / 1$ and $3.66 \mathrm{mg} / 1$ respectively. Iron (Fe) recorded $12.58 \mathrm{mg} / 1,11.90 \mathrm{mg} / 1,11.56 \mathrm{mg} / 1$ and $4.79 \mathrm{mg} / 1$ at USp, DP, USs and DSp respectively. The result of $\mathrm{Pb}$ at USp was $0.2 \mathrm{mg} / 1,0.01 \mathrm{mg} / 1$ in DP, $0.15 \mathrm{mg} / 1$ in USs and $0.015 \mathrm{mg} / 1$ in DSp. However, the results of $\mathrm{Pb}$ at USp and USs were above WHO acceptable limit for $\mathrm{Pb}$ concentration. The concentration of $\mathrm{Mg}$ at locations USp, DP, USs and DSp were $12.12 \mathrm{mg} / 1,8.75 \mathrm{mg} / 1,8.47 \mathrm{mg} / 1$, and $2.17 \mathrm{mg} / 1$ respectively. Meanwhile, all the results are below the WHO acceptable limit for Mg. The mean values of Co at USp, DP, USs and DSp recorded $0.47 \mathrm{mg} / 1,0.33 \mathrm{mg} / 1,0.29 \mathrm{mg} / 1$, and $0.65 \mathrm{mg} / 1$ respectively. 
These outcomes are in line with Prasad et al., (2012) who found that for nearly every water sampled from abandoned coal site and analyzed, there were heavy metal leachates that exceeded international water quality guidelines. It is also in line with Chayanan et al., (2014) and Geller et al., (1998) who confirmed that AMD often contains high concentrations of heavy metals, such as $\mathrm{Fe}, \mathrm{Mn}, \mathrm{Al}$ and anions like $\mathrm{SO}_{4}{ }^{2-}$ and $\mathrm{PO}_{4}{ }^{2-}$ in addition to elements like $\mathrm{Zn}, \mathrm{Co}, \mathrm{Pb}, \mathrm{Cr}, \mathrm{Cu}$ in trace concentrations. Production of heavily mineralised discharge waters is a phenomenon observed worldwide at active and abandoned mine sites (Wood et al., 1999; Blowes et al., 2003). Mine closure commonly results in increased concentrations of dissolved ions, particularly iron and sulphate, in mine discharge waters due to the dissolution of pyrite oxidation products formed, mainly, during the operational phase of the mine (Younger, 2000). The mean values of total dissolved solids (TDS) at the different stations may be attributed to the mineral contents of the water due to the elements present in the abandoned coal mine site. The level of EC at the stations may also be attributed to the presence of mineral ions in the water since. The recorded level of electrical conductivity (EC) is a function of TDS. Recorded mean values of temperature at the different stations are within the same range except for USp which may be due to exposure of the samples to sunlight since there were no trees. TS is the matter suspended or dissolved in water or wastewater, and is related to both specific conductance and turbidity. Total Solids includes both total suspended solids (TSS), the portion of total solids retained by a filter, and (TDS), the portion that passes through a filter. By the virtue of these explanation, TS and TSS concentrations in the water samples may be due partly to the leaves and other parts of the trees and grasses (which form debris) from near, far and wild areas of the water samples.

The presence of $\mathrm{Cl}_{2}$ and $\mathrm{NO}_{3}$ in the water samples may be due to the presence of metals (cations) which could bind freely with the anions to form normal salt and/or acidic salts. Potential Hydrogen $(\mathrm{pH})$ of the water samples at respective points are within the WHO standard. This may be due to dilution by rain water since the samples were collected during the rainy season. However, this refutes the reports of Geller et al., (1998) and Williams et al., (1996) who found $\mathrm{pH}$ value to be less than 4. The acidic level of the water sample at USp is high however, less than those of DP, USs and DSp stations. The high acidic level of the water samples from stations DP, USs and DSp may be due to AMD in the abandoned mining site which moves from upstream secondary (USs) to discharge point (DP) through downstream primary (DSp). The acidic level at USp may be due to contamination from other sources like detergents used in washing since it is an open surface water where people living around the area wash their cloths and take their bath. The discussions above are in line with Gzyl and Bank (2007) who stated that the main contaminants found in coal mine waters are high levels of proton acidity, $\mathrm{H}^{+}$, high metal concentrations, majorly $\mathrm{Fe}, \mathrm{Mn}, \mathrm{Al}, \mathrm{Ni}$ and very high concentrations of sulphate, SO4 ${ }^{2-}$, often collectively termed Acid Mine Drainage (AMD).

\subsection{Microbial load of the water samples from the coal mined site}

At upstream primary (USp) in the month of July, the total viable count (TVC) of the bacteria Pseudomonas aurogenosa and Bacillus substilis were $9.0 \times 10^{3} \mathrm{cfu} / \mathrm{ml}$ and $1.2 \times 10^{4} \mathrm{cfu} / \mathrm{ml}$ while in the month of August it was $9.0 \times 10^{3} \mathrm{cfu} / \mathrm{ml}$ and $1.3 \times 10^{4} \mathrm{cfu} / \mathrm{ml}$ respectively. The presence of these microorganism could be due to the fact that the mine water is acidic as earlier mention and so can sustain the lives of acidithiobacillus group like Bacillus and Pseudomonas auroginosa. These findings are in line with the reports of Mayes et al., (2008) and Natarajan (2008). Fungi present at this point were Aspergillus niger and Aspergillus flavus which were $1.2 \times 10 \mathrm{cfu} / \mathrm{ml}$ and $1.0 \times 102 \mathrm{cfu} / \mathrm{ml}$ respectively in the month of July and $1.3 \times 10 \mathrm{cfu} / \mathrm{ml}$ and $1.0 \times 102 \mathrm{cfu} / \mathrm{ml}$ by August. The presence of fungi could be due partly to the presence of debris in the water and the fact that microorganisms are ubiquitous. At point of discharge (PD), Streptococcus faecalis $\left(2.3 \times 10^{4} \mathrm{cfu} / \mathrm{ml}\right)$ and Klebsiella $\operatorname{Spp}\left(2.4 \times 10^{4} \mathrm{cfu} / \mathrm{ml}\right)$ were bacteria recorded in July. Streptococcus faecalis present was $2.3 \times 10^{4} \mathrm{cfu} / \mathrm{ml}$ and Klebsiella Spp was $2.4 \times 10^{4} \mathrm{cfu} / \mathrm{ml}$ in August. The presence of these two organisms could be attributed to the faecal matters around that found their way into the river water. The type and number of bacteria present at this station may still be attributed to the faecal particles in and around the water bodies. The same fungi present at USp were also present at PD at the same concentrations in the month of July. However, in August, Aspergillus niger increased to $1.3 \times 10^{2}$. At $100 \mathrm{~m}$ upstream of Orobo river from the point of discharge labeled USs (Upstream secondary), E. coli $\left(1.2 \times 10^{2} \mathrm{cfu} / \mathrm{ml}\right)$, Pseudomonas aurogenosa $\left(1.0 \times 10^{2} \mathrm{cfu} / \mathrm{ml}\right)$, Salmonella $\operatorname{Spp}(1.0$ $\left.\times 10^{3} \mathrm{cfu} / \mathrm{ml}\right)$ were present while the only fungus present was Aspergillus niger $\left(1.0 \times 10^{2} \mathrm{mg} / \mathrm{l}\right)$ in the month of July. In August, it was only the total viable count (TVC) of E. coli and Bacillus subtillis that increased to 2.7 $\times 10^{3} \mathrm{cfu} / \mathrm{ml}$ and $3.4 \times 10^{2} \mathrm{cfu} / \mathrm{ml}$ respectively. The faecal coliform (E. coli, Salmonella Spp) are indications that 
outside the AMD, the water bodies are contaminated with faecal matter. The presence of Bacillus subtillis and Pseudomonas aurogenosa at this point is an indication that the same quality of water at upstream primary flows down to the point of discharge. The presence of these two microbes is also in line with the reports of Mayes et al., (2008) and Natarajan (2008). At the fourth location, $100 \mathrm{~m}$ downstream from the point of mine water discharge labeled DSp (Downstream primary), the bacteria present in the July include E. coli $\left(2.4 \times 10^{3} \mathrm{cfu} / \mathrm{ml}\right)$, Bacillus substillis $\left(3.8 \times 10^{2} \mathrm{cfu} / \mathrm{ml}\right)$, Salmonella Spp $\left(1.9 \times 10^{3} \mathrm{cfu} / \mathrm{ml}\right)$ and Streptococus faecalis $\left(1.9 \times 10^{4} \mathrm{cfu} / \mathrm{ml}\right)$. The bacteria present at downstream primary are indications that at the meeting point of Orobo and Nyama rivers, the microbial load of the water sample remains the same as it flows down the major river. Aspergillus flavus of $1.3 \times 10^{2} \mathrm{cfu} / \mathrm{ml}$ was the only fungus recorded present at this point. In August, the TVC of other microbes remained the same except for E. coli, Salmonella $S p p$ and Aspergillus flavus which were $1.8 \times 10^{2} \mathrm{cfu} / \mathrm{ml}, 1.2$ $\times 10^{3} \mathrm{cfu} / \mathrm{ml}$ and $1.4 \times 10^{2} \mathrm{cfu} / \mathrm{ml}$ respectively. The reduction in the microbial load in August may be due to lack of required nutrients for the microbial growth.

\subsection{Statistical analysis}

To test the hypotheses that guide this study, Analysis of variance (ANOVA) was used to test for significant differences at $\mathrm{P} \leq 0.05$. The treatment means were separated using Duncan's multiple range test (DMRT). At $95 \%$ confidence level, there is no statistically significant difference in the parameters of the water samples within months (July and August). For all the parameters, $\alpha$-significant at $\mathrm{P} \leq 0.05$ fall within .207 and .995 .

Duncan's multiple range test (DMRT) shows that with the exception of temperature, there is significant difference in the parameters of the water samples collected at different stations (Table 3). For all the parameters, alpha $(\alpha)$ is significant at $\mathrm{P} \leq 0.05$. In table 4 , DMRT shows that with the exception of Lead $(\mathrm{Pb})$, there is significant difference $(\mathrm{p} \leq 0.05)$ in the heavy metals found in the water samples collected at different stations.

Table 3: Physico-chemical composition of the water samples

\begin{tabular}{|c|c|c|c|c|c|c|c|c|c|c|c|c|}
\hline \multirow{2}{*}{$\begin{array}{l}\text { Statio } \\
\text { ns }\end{array}$} & \multicolumn{12}{|c|}{ Physicochemical Parameters } \\
\hline & $\begin{array}{l}\text { TDS } \\
(\mathrm{mg} / \mathrm{l})\end{array}$ & $\begin{array}{l}\mathrm{EC} \\
(\mu \mathrm{s} / \mathrm{m})\end{array}$ & $\begin{array}{l}\text { Temp } \\
\left({ }^{0} \mathrm{c}\right)\end{array}$ & $\begin{array}{l}\mathrm{TS} \\
(\mathrm{mg} / \mathrm{l})\end{array}$ & $\begin{array}{l}\mathrm{TSS}(\mathrm{Mg} / \\
\text { 1) }\end{array}$ & $\mathrm{pH}$ & $\begin{array}{l}\mathrm{AL}(\mathrm{mg} \\
/ 1)\end{array}$ & $\mathrm{AC}(\mathrm{mg} / \mathrm{l}$ & $\begin{array}{l}\mathrm{PO}_{4}(\mathrm{~m} \\
\mathrm{g} / \mathrm{l})\end{array}$ & $\begin{array}{l}\mathrm{Cl}_{2}(\mathrm{mg} / \\
\text { 1) }\end{array}$ & $\begin{array}{l}\mathrm{NO}_{3}(\mathrm{mg} / \\
\text { 1) }\end{array}$ & $\begin{array}{l}\mathrm{SO}_{4}(\mathrm{mg} / \\
1)\end{array}$ \\
\hline USp & $\begin{array}{l}62.5 \pm 3 \\
53^{\mathrm{a}}\end{array}$ & $\begin{array}{l}49.7 \pm 04 \\
2^{\mathrm{a}}\end{array}$ & $\begin{array}{l}27.45 \pm 1 \\
.34^{\mathrm{a}}\end{array}$ & $\begin{array}{l}103.70 \pm 0 \\
.85^{\mathrm{a}}\end{array}$ & $\begin{array}{l}121.65 \pm 2 \\
.05^{\mathrm{a}}\end{array}$ & $\begin{array}{l}5.95 \pm 0 . \\
07^{\mathrm{a}}\end{array}$ & $\begin{array}{l}3.20 \pm 0 \\
15^{\mathrm{a}}\end{array}$ & $\begin{array}{l}15.40 \pm 0 . \\
148^{\mathrm{a}}\end{array}$ & $\begin{array}{l}2.08 \pm 0 . \\
42^{\mathrm{a}}\end{array}$ & $\begin{array}{l}279 \pm 1 . \\
4^{\mathrm{a}}\end{array}$ & $\begin{array}{l}10.13 \pm 0 . \\
064^{\mathrm{a}}\end{array}$ & $\begin{array}{l}430.0 \pm 1 \\
4.1^{\mathrm{a}}\end{array}$ \\
\hline $\mathrm{Dp}$ & $\begin{array}{l}20.25 \pm 0 \\
.35^{\mathrm{b}}\end{array}$ & $\begin{array}{l}49.54 \pm 0 \\
.65^{\mathrm{a}}\end{array}$ & $\begin{array}{l}28.0 \pm 0 . \\
14^{\mathrm{a}}\end{array}$ & $\begin{array}{l}106.7 \pm 0 . \\
57^{\mathrm{b}}\end{array}$ & $\begin{array}{l}111.0 \pm 1 \\
4^{\mathrm{b}}\end{array}$ & $\begin{array}{l}6.90 \pm 0 . \\
00^{\mathrm{b}}\end{array}$ & $\begin{array}{l}1.95 \pm 0 . \\
78^{\mathrm{b}}\end{array}$ & $\begin{array}{l}10.09 \pm 0 . \\
85^{\mathrm{b}}\end{array}$ & $\begin{array}{l}0.80 \pm 0 . \\
03^{b}\end{array}$ & $\begin{array}{l}94.6 \pm 0 . \\
79^{\mathrm{b}}\end{array}$ & $\begin{array}{l}5.69 \pm 0.1 \\
8^{b}\end{array}$ & $\begin{array}{l}79.52 \pm 0 \\
.7^{\mathrm{b}}\end{array}$ \\
\hline USs & $\begin{array}{l}10.0 \pm 0 . \\
00^{c}\end{array}$ & $\begin{array}{l}200.0 \pm 0 \\
.00^{\mathrm{b}}\end{array}$ & $\begin{array}{l}27.5 \pm 0 \\
10^{\mathrm{a}}\end{array}$ & $\begin{array}{l}111.55 \pm 0 \\
.64^{\mathrm{c}}\end{array}$ & $\begin{array}{l}116.45 \pm 0 \\
.21^{\mathrm{c}}\end{array}$ & $\begin{array}{l}7.60 \pm 0 . \\
14^{\mathrm{c}}\end{array}$ & $\begin{array}{l}1.95 \pm 0 . \\
78^{\mathrm{b}}\end{array}$ & $\begin{array}{l}10.12 \pm 0 . \\
63^{\mathrm{b}}\end{array}$ & $\begin{array}{l}0.78 \pm 0 \\
64^{\mathrm{b}}\end{array}$ & $\begin{array}{l}94.1 \pm 1 . \\
47^{\mathrm{b}}\end{array}$ & $\begin{array}{l}5.46 \pm 0.1 \\
5^{b}\end{array}$ & $\begin{array}{l}79.82 \pm 0 \\
.18^{\mathrm{b}}\end{array}$ \\
\hline $\mathrm{DSp}$ & $\begin{array}{l}20.0 \pm 0 . \\
00^{\mathrm{b}}\end{array}$ & $\begin{array}{l}30.0 \pm 0 . \\
00^{c}\end{array}$ & $\begin{array}{l}28.40 \pm 0 \\
.28^{\mathrm{a}}\end{array}$ & $\begin{array}{l}11.0 \pm 0.1 \\
4^{\mathrm{d}}\end{array}$ & $\begin{array}{l}20.99 \pm 0 . \\
156^{\mathrm{d}}\end{array}$ & $\begin{array}{l}6.00 \pm 0 . \\
00^{\mathrm{a}}\end{array}$ & $\begin{array}{l}2.93 \pm 1 . \\
0^{\mathrm{a}}\end{array}$ & $\begin{array}{l}13.10 \pm 0 . \\
00^{\mathrm{c}}\end{array}$ & $\begin{array}{l}0.47 \pm 0 . \\
14^{\mathrm{c}}\end{array}$ & $\begin{array}{l}45.1 \pm 0 . \\
07^{\mathrm{c}}\end{array}$ & $\begin{array}{l}2.25 \pm 0.2 \\
1^{\mathrm{c}}\end{array}$ & $\begin{array}{l}64.90 \pm 0 \\
.14^{\mathrm{b}}\end{array}$ \\
\hline $\begin{array}{l}\text { WH } \\
\text { O } \\
\text { Limit } \\
(2006\end{array}$ & 500 & 500 & 30 & 30 & & $6.5-9.5$ & & & 5 & 250 & 50 & 500 \\
\hline
\end{tabular}

Data are presented as MEAN + SEM, $n=4$.

Means with the same superscript in the same column are not statistically significant at $(\mathrm{P} \leq 0.05)$

WHO standard is included for comparison. 
Table 4: Trace metal composition of the water samples

\begin{tabular}{|c|c|c|c|c|c|c|c|c|c|}
\hline \multirow{2}{*}{ Stations } & \multicolumn{9}{|c|}{ Elements } \\
\hline & $\begin{array}{c}\mathrm{Zn} \\
(\mathrm{mg} / \mathrm{l})\end{array}$ & $\mathrm{K}(\mathrm{mg} / \mathrm{l})$ & $\begin{array}{c}\mathrm{Cu} \\
(\mathrm{mg} / \mathrm{l})\end{array}$ & $\begin{array}{c}\mathrm{Na} \\
(\mathrm{mg} / \mathrm{l})\end{array}$ & $\mathrm{Ca}(\mathrm{mg} / \mathrm{l})$ & $\mathrm{Fe}(\mathrm{mg} / \mathrm{l})$ & $\mathrm{Pb} \mathrm{mg} / \mathrm{l})$ & $\mathrm{Mg}(\mathrm{mg} / \mathrm{l})$ & Co $(\mathrm{mg} / \mathrm{l})$ \\
\hline $\begin{array}{l}100 \mathrm{~m} \\
\mathrm{USp}\end{array}$ & $1.51 \pm 0.57$ & $26.11 \pm 0.1^{\mathrm{a}}$ & $\begin{array}{l}0.06 \pm 0.01 \\
4\end{array}$ & $\begin{array}{l}54.5 \pm 0.262 \\
\text { a }\end{array}$ & $\begin{array}{l}22.12 \pm 0.85 \\
\mathrm{a}\end{array}$ & $12.58 \pm 0.21$ & $0.2 \pm 0.00^{\mathrm{a}}$ & $12.12 \pm 0.03$ & $0.47 \pm 0.7^{\mathrm{a}}$ \\
\hline DP & $\begin{array}{l}1.32 \pm 0.01 \\
\mathrm{~b}\end{array}$ & $\begin{array}{l}\text { b } \\
\text { b }\end{array}$ & $\begin{array}{l}0.02 \pm 0.00 \\
7\end{array}$ & $8.45 \pm 0.78^{b}$ & $9.17 \pm 0.28^{b}$ & $\begin{array}{l}11.90 \pm 0.01 \\
\text { a }\end{array}$ & $0.01 \pm 0.00^{\mathrm{a}}$ & $8.75 \pm 0.22^{b}$ & $0.33 \pm 0.78^{a}$ \\
\hline $\begin{array}{l}100 \mathrm{~m} \\
\mathrm{USs}\end{array}$ & $\begin{array}{l}1.32 \pm 0.06 \\
\mathrm{~b}\end{array}$ & $\begin{array}{l}15.84 \pm 0.148 \\
\text { b }\end{array}$ & $\begin{array}{l}0.02 \pm 0.01 \\
4\end{array}$ & $8.40 \pm 0.15^{b}$ & $9.1 \pm 0.13^{b}$ & $\begin{array}{l}11.56 \pm 0.69 \\
\text { a }\end{array}$ & $0.15 \pm 0.00^{\mathrm{a}}$ & $8.47 \pm 0.69^{b}$ & $\begin{array}{l}0.29 \pm 0.13^{\text {(b }} \\
\text { )(a) }\end{array}$ \\
\hline$\overline{D S p}$ & $\begin{array}{l}1.04 \pm 0.57 \\
\mathrm{c}\end{array}$ & $8.34 \pm 0.20^{\mathrm{c}}$ & NAD & $6.28 \pm 0.17^{\mathrm{c}}$ & $3.66 \pm 0.28^{c}$ & $4.79 \pm 0.23^{b}$ & $\begin{array}{l}0.015 \pm 0.01 \\
\mathrm{a}\end{array}$ & $2.17 \pm 0.40^{\mathrm{c}}$ & $0.65 \pm 0.35^{b}$ \\
\hline $\begin{array}{l}\text { WHO } \\
\text { Standar } \\
\text { d }\end{array}$ & 5.0 & & 0.2 & & & & 0.01 & 200 & \\
\hline
\end{tabular}

Data are presented as MEAN + SEM, $n=4$.

Means with the same superscript in the same column are not statistically significant at $(\mathrm{P} \leq 0.05)$.

WHO standard is included for comparison.

$\mathrm{NAD}=$ Not available for detection

\subsection{Conclusion and Recommendations}

The abandoned coal mine sites contribute to the type as well as the concentration of microorganisms and heavy metals present in the water samples. Consequently, the microbial load and the physicochemical parameters/indicators of water quality are affected negatively. Statistically, there is no significant difference in the quality of the surface water samples between the months of July and August and therefore, the level of pollution is the same. Faecal coliforms are the major microbial contaminants of the surface waters investigated and may be due to open defecation system within the vicinity of the abandoned mine sites which are point sources of surface water. The consideration of the health effects of the cessation of coal mining in Okpara mine within the area has been a worthwhile endeavour especially in the light of the fact that the source of drinking water for the people largely depend on the contaminated surface water. The health issue which anchors this study form an integral part of the principles of sustainable drinking water supply. Hence, an integrated approach involving all stakeholders is needed to address the potential health reality of the community members. Any programme of intervention now should target the broadening of alternative sources of drinking water for the community. 


\section{Appendix I}

Table 1: Mean values of physicochemical parameters of the water samples from the coal mined site

\begin{tabular}{|c|c|c|c|c|c|c|c|c|c|c|c|c|}
\hline \multirow[t]{2}{*}{ Stations } & \multicolumn{12}{|c|}{ Physicochemical Parameters } \\
\hline & $\begin{array}{l}\text { TDS } \\
(\mathrm{mg} / \mathrm{l})\end{array}$ & $\begin{array}{l}\mathrm{EC} \\
(\mu \mathrm{s} / \mathrm{m})\end{array}$ & $\begin{array}{l}\text { Temp } \\
\left({ }^{0} \mathrm{c}\right)\end{array}$ & $\begin{array}{l}\mathrm{TS} \\
(\mathrm{mg} / \mathrm{l})\end{array}$ & $\begin{array}{l}\mathrm{TSS} \\
(\mathrm{mg} / \mathrm{l})\end{array}$ & $\mathrm{pH}$ & $\begin{array}{l}\mathrm{AL} \\
(\mathrm{mg} / \mathrm{l})\end{array}$ & $\begin{array}{l}\mathrm{AC} \\
(\mathrm{mg} / \mathrm{l})\end{array}$ & $\begin{array}{l}\mathrm{PO}_{4} \\
(\mathrm{mg} / \mathrm{l})\end{array}$ & $\begin{array}{l}\mathrm{Cl}_{2} \\
(\mathrm{mg} / \mathrm{l})\end{array}$ & $\begin{array}{l}\mathrm{NO}_{3} \\
(\mathrm{mg} / \mathrm{l})\end{array}$ & $\begin{array}{l}\mathrm{SO}_{4} \\
(\mathrm{mg} / \mathrm{l})\end{array}$ \\
\hline USp & 62.5 & 49.7 & 27.45 & 103.70 & 121.65 & 5.95 & 3.20 & 15.40 & 2.08 & 279 & 10.13 & 430.0 \\
\hline $\mathrm{Dp}$ & 20.25 & 49.54 & 28.0 & 106.7 & 111.0 & 6.90 & 1.95 & 10.09 & 0.80 & 94.6 & 5.69 & 79.52 \\
\hline USs & 10.0 & 200.0 & 27.5 & 111.55 & 116.45 & 7.60 & 1.95 & 10.12 & 0.78 & 94.1 & 5.46 & 79.82 \\
\hline $\mathrm{DSp}$ & 20.0 & 30.0 & 28.40 & 11.0 & 20.99 & 6.00 & 2.93 & 13.10 & 0.47 & 45.1 & 2.25 & 64.90 \\
\hline $\begin{array}{l}\text { WHO } \\
\text { Limit } \\
(2006)\end{array}$ & 500 & 500 & 30 & 30 & & $\begin{array}{l}6.5- \\
9.5\end{array}$ & & & 5 & 250 & 50 & 500 \\
\hline
\end{tabular}

Key: $U S p=$ Upstream primary, $\mathrm{DP}=$ Discharge point, $U S s=$ Upstream secondary, $\mathrm{DSp}=$ Downstream primary, TDS $=$ Total Dissolved Solid, EC = Conductivity, TSS $=$ Total Suspended Solid, TS $=$ Total Solid, $\mathrm{pH}=$ Potential hydrogen, $\mathrm{AL}=$ Alkalinity, $\mathrm{AC}=$ Acidity, $\mathrm{PO}_{4}=$ Phosphate, $\mathrm{Cl}=$ Chloride, $\mathrm{NO}_{3}=$ Nitrate, $\mathrm{SO}_{4}=$ Sulphate

\section{Appendix II}

Table 2: Mean values of the Elements in the water samples from the coal mined site

\begin{tabular}{|l|l|l|l|l|l|l|l|l|l|}
\hline \multirow{2}{*}{ Stations } & \multicolumn{9}{|c|}{ Elements (Trace Metals) } \\
\cline { 2 - 10 } & $\mathrm{Zn}(\mathrm{mg} / \mathrm{l})$ & $\begin{array}{c}\mathrm{K} \\
(\mathrm{mg} / \mathrm{l})\end{array}$ & $\begin{array}{l}\mathrm{Cu} \\
(\mathrm{mg} / \mathrm{l})\end{array}$ & $\begin{array}{l}\mathrm{Na} \\
(\mathrm{mg} / \mathrm{l})\end{array}$ & $\begin{array}{l}\mathrm{Ca} \\
(\mathrm{mg} / \mathrm{l})\end{array}$ & $\begin{array}{c}\mathrm{Fe} \\
(\mathrm{mg} / \mathrm{l})\end{array}$ & $\begin{array}{l}\mathrm{Pb} \\
(\mathrm{mg} / \mathrm{l})\end{array}$ & $\begin{array}{l}\mathrm{Mg} \\
(\mathrm{mg} / \mathrm{l})\end{array}$ & $\begin{array}{c}\text { Co } \\
(\mathrm{mg} / \mathrm{l})\end{array}$ \\
\hline USp & 1.51 & 26.11 & 0.06 & 54.5 & 22.12 & 12.58 & 0.2 & 12.12 & 0.47 \\
\hline DP & 1.32 & 15.90 & 0.02 & 8.45 & 9.17 & 11.90 & 0.01 & 8.75 & 0.33 \\
\hline USs & 1.32 & 15.84 & 0.02 & 8.40 & 9.1 & 11.56 & 0.15 & 8.47 & 0.29 \\
\hline DSp & 1.04 & 8.34 & NAD & 6.28 & 3.66 & 4.79 & 0.015 & 2.17 & 0.65 \\
\hline $\begin{array}{l}\text { WHO } \\
\text { Standard }\end{array}$ & 5.0 & & 0.2 & & & & 0.01 & 200 & \\
\hline
\end{tabular}

Key: $U S p=$ Upstream primary, DP $=$ Discharge point, USs= Upstream secondary, $\mathrm{DSp}=$ Downstream primary, $\mathrm{Zn}=$ Zinc,

$\mathrm{K}=$ Potassium, $\mathrm{Cu}=$ Cupper, $\mathrm{Na}=$ Sodium, $\mathrm{Ca}=$ Calcium, $\mathrm{Cd}=$ Cadmium, $\mathrm{Cu}=$ Copper, $\mathrm{Fe}=\mathrm{Iron}, \mathrm{Pb}=$ Lead,

$\mathrm{Mg}=$ Magnesium, $\mathrm{Co}=$ Cobalt, NAD $=$ Not Available for Detection.

\section{References}

AOAC (2005) Official Method of Analysis. 18th Edition, Association of Officiating Analytical Chemists, Washington DC, Method 935.14 and 992.24. 
Awaomim J. Y (2013). Effects of abandoned open-mine pits on property values in Dorowa, Nigeria. Department of Estate Management and Valuation, Federal Polytechnic, Nasarawa. Paper presented at the African Real Estate Society Conference in Kigali, Rwanda.

Blowes D.W., Ptacek C.J., Janbor J.L., Weisener C.G., 2003 The geochemistry of acid mine drainage, In: Treatise on Geochemistry, Vol. 9: Environmental Geochemistry; p. 149-204.

Chayanan J, Somporn C and Chitchol P (2014). Heavy Metals and Ion Concentrations in Acidic Coal Mine Reservoir in Lamphun Province, Thailand. ISSN 2315-6147. Scholarly Journal of Biological Science Vol. 3(2), pp. 18-24. [Online]; Available at: http:// www.scholarly-journals.com/SJBS

Cidu, R., Biddau, R., Fanfani, L.(2009). Impact of past mining activity on the quality of groundwater in SW Sardinia (Italy). Journal of Geochemical Exploration 100, 125-132.

Enugu State Ministry of Lands and Survey (2012) Maps of Enugu State and Enugu Metropolis.

Floyd B.(1969). Eastern Nigeria: a geographical review. Praeger

Geller, W., Klapper, H. and Schultze, M. (1998). Natural and anthropogenic sulfuric acidification of lakes. In: Geller, W., Klapper, W., Salomons, W. (Eds.), Acidic Mining Lakes, Springer Berlin. pp. 3 - 15.

Grzl, G., Banks, D., (2007). Verification of the 'first flush' phenomenon in mine water from coal mines in the Upper Silesian Coal Basin, Poland, Journal of Contaminant Hydrology 92, 66-86.

Gyang, J.D and Ashano, E.C. (2010). Effects of Mining on Water Quality and the Environment: A Case Study of Parts of the Jos Plateau, North Central Nigeria. Pacific Journal of Science and Technology. 11(1): 631639.

Holt J. G (1993) Bergey's Manual of Determinative Bacteriology, $9^{\text {th }}$ ed. ISBN: 9780683006032

Jarvis A. P, Younger P. L. (1997). Dominating chemical factors in mine water induced impoverishment of the invertebrate fauna of two streams in the Durham coalfield, UK. ChemEcol, 13:249-270.

Johnston, D., Potter, H., Jones, C., Rolley, S., Watson, I., Pritchard, J., Environment Agency, (2008), Abandoned mines and the water environment, Science project SC030136-41.

KnÖller, K., Fauville, A., Mayerc, B., Strauch, G., Friese, K. and Veizer, J. (2004). Sulfur cycling in an acid mining lake and its vicinity in Lusatia, Germany. Chem. Geol. 204: 303-323

Kitula, A. G. N (2005). The environmental and socio-economic impacts of mining on local livelihoods in Tanzania: A case study of Geita District. Journal of Cleaner Production (14) $405-414$.

Lottermoser, B. G (2010). Mine Wastes, 3rd ed., Spronger-Verlag Berlin Heidelberg Louw, S.J., Addison, J., 1985. Studies of the Scottish Oil Shale Industry, volume1, history and mineralogy, Institute of Occupational Medicine, historical research report, TM/85/02

Mba H. C (2004). Management of environmental problems and hazards in Nigeria. Ashgate Publishing, Ltd. p. 291. ISBN 978-0-7546-1394-7.

Mayes, W. M., Gozzard, E., Potter, H. A. B., Jarvis, A. P (2008). Quantifying the importance of diffuse mine water pollution in a historically heavily coal mined catchment, Environmental Pollution 151, 165-175.

Natarajan, K. A., (2008). The Microbial aspects of acid mine drainage and its bioremediation, Transactions of Nonferrous Metals Society of China 18, 1352-1360

Nordstrom, D. K. (2011). Hydrochemical processes governing the origin, transport and fate of major and trace elements from mine waste and mineralized rock to surface waters. Applied Geochemistry 26, 1777-1791 
Odoemene A.C (n.d). Explaining Inter-Ethnic Coexistence and Harmony in Enugu city, Southeastern Nigeria. University of Ibadan: 9-13

Prasad N, Clevo, W and Wasantha, A. (2012). The Impact of Mining and Smelting Activities on Property Values: A Study of Mount Isa City, Queensland, Australia. The Australian Journal of Agricultural and Resource Economics, 57: 60-78

Ripley, E. A, Redman, R and Crowder, A (1996). Environmental Effects of Mining: St. Lucie Press Delray Beach, Florida

Thomas, L (2002). Coal geology (reprint ed.). Nigeria: John Wiley and Sons. p. 64. ISBN 0-471-48531-4.

US EPA (2009). Quality Criteria for Water. EPA-440/9-76-023, United States Environmental Protection Agency, Washington, D.C.

Washington's Department of Natural Resources (1996). Protection and sustainable use of waters: agricultural policy requirements in USA. HRVAT. VODE, 4(15), 69-76.

Wikipedia (2013) "Enugu" in Wikipedia, the free encyclopedia. Available at http://en.wikipedia.org/wiki/Enugu. Last accessed 17/10/2012.

Williams, D.R., Sams III, J.I., and Mulkerrin, M.E (1996). Effects of coal mine discharges on the quality of the Stonycreek River and its tributaries, Somerset and Cambria Counties, Pennsylvania: U.S. Geological Survey Water-Resources Investigations Report 96-4133, 95 p.

Wood S. C., Younger P. L., Robins N. S. (1999). Long-term changes in the quality of polluted Mine water discharges from abandoned coal workings in Scotland. QJ Eng Geol; 32(1): 69-79.

Young, J.E. (1992). Mining the earth. Worldwatch Paper, vol. 109. Worldwatch Institute; p. 53.

Younger, P.L. (1992). Mine water pollution: the revenge of old king coal. Geoscientist. 4(5): 6-8.

Younger, P.L., 1995. Hydrogeochemistry of Mine waters Flowing from Abandoned Coal Workings in County Durham. Q J Eng Geol 28, S101-S113.

Younger, P.L., (2000). Predicting temporal changes in iron concentrations in groundwaters flowing from abandoned deep mines: a first approximation. Journal of Contaminant Hydrology 44, 47-69. 